\title{
Does Meaningful Relationship Exist Between Trade Liberalization and Economic Growth? A Case Study of a Small Open Economy
}

\author{
Adedapo Odebode ${ }^{1}$ and Olajide Sunday Oladipo*2
}

\begin{abstract}
Using quarterly data between 1981q1 and 2018q4, the paper investigates the relationship between trade liberalization and economic growth in Nigeria. Exploring Johnasen cointegration technique and the Vector Error Correction (VEC) method, the paper considers three alternative measures of trade liberalization to determine whether the response of economic growth to trade liberalization is sensitive to the choice of the indicators of trade liberalization under consideration. The paper finds significant effects of trade liberalization on the economy. The paper recommends that government should implement policies that will promote trade openness in Nigeria. This may be achieved by establishing bilateral and multilateral agreements that are favourable and that will support appropriate technology transfer to domestic producers.
\end{abstract}

JEL classification numbers: F31, F13, F41.

Keywords: Trade liberalization, Tariffs, Economic growth, Nigeria.

\footnotetext{
${ }^{1}$ Banking Services Department, Central Bank of Nigeria (CBN), Central Business District, Abuja, Nigeria.

2 Department of Economic Development and Social Studies (EDSS), National Institute for Legislative and Democratic Studies (NILDS), National Assembly, Abuja, Nigeria.

* Corresponding Author
}

Article Info: Received: February 18, 2021. Revised: March 15, 2021.

Published online: March 22, 2021. 


\section{Introduction}

As with some developing economies in the 1980s, trade liberalization in Nigeria can be formally traced to the policy conditionality central to the then World Bank Structural Adjustment Programmes (SAPs), with trade reforms accounting for a higher proportion of loan conditions than any other. According to Greenaway et al. (2002), the fundamental rationale for such degree of commitment to programmes of trade reform is motivated by the obvious belief that trade liberalization is a prerequisite to the actualisation of the quest for transition from a relatively closed to a relatively open economy. Worldwide, the basic underlying intuition behind trade liberalization is essentially to promote free flow of cross boarder trading activities by eliminating all restrictions and barriers to trade.

Due to the assertion that trade liberalization and, partially, by extension, has the potential for enhancing economic performance, the Nigerian economy has since embraced and undergone a number of trade liberalization policies including decrease in both duties and non-tariff barriers. The trade liberalization policies, in particular, may equally not be unconnected to the widespread assertion attributing the impressive economic growth and industrialization process in some of the (now referred) developed countries to proactive trade policies, rather than reliance on unfettered market forces, see Rodrik (2016). Although this portends trade liberalization as potential for enhancing economic growth, a relatively large percentage of extant studies on liberalization appears to be both largely mixed and inconclusive in their findings of the nature and direction of relationship between economic growth and trade liberalization, see Manwa et al., (2019), Gnangnon, (2018), Titus and Abiodun (2017), Manwa and Wijeweera (2016), Bhattacharyya (2012), and Rodriguez and Rodrik (2000).

Rodriguez and Rodrik (2000) from the theoretical perspective, reaffirmed the erratic nature of the existing findings on the impact of trade liberalization on economic growth and reveal that trade liberalization under the assumption of endogenous growth model may increase global output, but not necessarily the output of all countries. In addition, Krugman and Obstfeld (2008), and Salvatore (2011) subscribed to the classical growth models' prediction under the assumption of constant returns to scale, that the removal of trade restrictions should not have a permanent effect on long run economic growth.

In an attempt at validating or refuting the above theoretical position, various extant studies have attributed lack of consistency in the existing empirical results to the usage of different trade liberalization indicators, see Bhagwati and Srinivasan (2002), and Anderson and Neary (1996). Thus, in addition to exploring short and long run dynamics of the potential impacts of trade liberalization on economic growth using autoregressive distributed lag (ARDL) modelling framework, authors also contributed to the literature by considering alternative measures of trade liberalization, particularly in the context of Nigeria. Essentially, this study considers three indicators of trade liberalization: Trade Ratio/Trade Openness, see Dowrick and Golley (2004), Dollar and Kraay (2004), Yanikkaya (2003); for tariffs, see 
Anderson and Neary (2003), Harrison (1996), Pritchett and Sethi (1994), and for real effective exchange rates, see Rodrik (2008), Eichengreen (2007), Hausmann et al., (2005), Doganlar (2002) among others.

However, unlike other previous studies, where only one of these alternative measures of trade liberalization was considered, this present study adopts the approach of Manwa et al. (2019) by doing a comparison of all these indicators. Following the introduction, the paper is structured as follows: Section two presents the empirical review of the previous findings on the relationship between trade liberalization relationship and economic growth. Section three focuses on methodology while section four focuses on the empirical results and discussions. The last section concludes the paper.

\section{Literature Review}

The relationship between export and economic growth has been discussed at both theoretical and empirical levels and there is a consensus that export, ceteris paribus, leads to economic growth. Given the spate of trade liberalization in developing countries since early 1990s, attention has shifted from the relationship between export and economic growth to the impact of trade liberalization on economic growth. It is surprising that there is no consensus on the impact of trade liberalization on economic growth. As a result the relationship between trade liberalization and growth is still a subject of debate and counter debate.

\section{Table 1: Summary of Empirical Literature}

\begin{tabular}{|c|c|c|c|}
\hline Author(s) & Regions/Countries & Methodology & Findings \\
\hline $\begin{array}{l}\text { Manwa et al. } \\
\text { (2019) }\end{array}$ & $\begin{array}{l}\text { Five Southern African } \\
\text { Customs Union } \\
\text { (SACU) countries }\end{array}$ & $\begin{array}{l}\text { Endogenous growth model } \\
\text { estimated using both static } \\
\text { and dynamic panel data } \\
\text { estimators }\end{array}$ & $\begin{array}{l}\text { The study finds only little evidence that } \\
\text { trade liberalization has a positive } \\
\text { impact on the economic growth of } \\
\text { SACU countries }\end{array}$ \\
\hline $\begin{array}{l}\text { Gnangnon } \\
\text { (2018) }\end{array}$ & 150 countries & $\begin{array}{l}\text { Dynamic panel model } \\
\text { using difference and } \\
\text { system GMM estimators }\end{array}$ & $\begin{array}{l}\text { The paper finds a strong positive } \\
\text { impact of multilateral trade } \\
\text { liberalization on economic growth in } \\
\text { both entire sample and sub-samples } \\
\text { alike. }\end{array}$ \\
\hline $\begin{array}{c}\text { Khobai and } \\
\text { Chitauro (2018) }\end{array}$ & Switzerland & $\begin{array}{l}\text { Auto-Regressive } \\
\text { Distributive Lag (ARDL) }\end{array}$ & $\begin{array}{l}\text { The empirical findings indicate that } \\
\text { trade openness had a positive and } \\
\text { significant effect on economic growth } \\
\text { in Switzerland. }\end{array}$ \\
\hline $\begin{array}{l}\text { Khobai et al. } \\
\text { (2018) }\end{array}$ & Ghana and Nigeria & $\begin{array}{l}\text { Auto-Regressive } \\
\text { Distributive Lag (ARDL) }\end{array}$ & $\begin{array}{l}\text { The study established that trade } \\
\text { openness has a positive and significant } \\
\text { effect on economic growth in Ghana } \\
\text { but a negative and insignificant effect } \\
\text { on economic growth in Nigeria. }\end{array}$ \\
\hline $\begin{array}{l}\text { Moyo and Khobai } \\
\text { (2018) }\end{array}$ & SADC & $\begin{array}{l}\text { ARDL-bounds test } \\
\text { approach and the Pooled } \\
\text { Mean Group model }\end{array}$ & $\begin{array}{l}\text { The results revealed trade openness has } \\
\text { a negative impact on economic growth } \\
\text { in the long-run. }\end{array}$ \\
\hline
\end{tabular}




\begin{tabular}{|c|c|c|c|}
\hline $\begin{array}{c}\text { Keho and Wang } \\
\text { (2017) }\end{array}$ & Cote d'Ivoire & $\begin{array}{l}\text { ARDL bounds test } \\
\text { and the Toda and } \\
\text { Yamamoto Granger } \\
\text { causality test }\end{array}$ & $\begin{array}{l}\text { The study revealed that trade openness } \\
\text { has a positive short run and long run } \\
\text { effect on economic growth. }\end{array}$ \\
\hline $\begin{array}{l}\text { Nteegah et al. } \\
\text { (2017) }\end{array}$ & Tanzania & $\begin{array}{l}\text { Auto Regressive } \\
\text { Distributed Lag method }\end{array}$ & $\begin{array}{l}\text { The study finds a positive and } \\
\text { significant impact on economic growth } \\
\text { in Tanzania. }\end{array}$ \\
\hline $\begin{array}{c}\text { Titus and } \\
\text { Abiodun (2017) }\end{array}$ & Nigeria & $\begin{array}{l}\text { The Generalized Method } \\
\text { of Moment technique }\end{array}$ & $\begin{array}{l}\text { The study finds a significant positive } \\
\text { impact of trade liberalization on the } \\
\text { output of agricultural sector but a } \\
\text { negative impact on the manufacturing } \\
\text { output in Nigeria. }\end{array}$ \\
\hline $\begin{array}{l}\text { Manwa and } \\
\text { Wijeweera } \\
\text { (2016) }\end{array}$ & $\begin{array}{l}\text { Five Southern African } \\
\text { Customs Union } \\
\text { (SACU) countries }\end{array}$ & $\begin{array}{l}\text { The auto-regressive } \\
\text { distributed lag (ARDL) } \\
\text { framework }\end{array}$ & $\begin{array}{l}\text { The study shows when compared to } \\
\text { other member countries in the SACU, } \\
\text { South Africa is the country with clear } \\
\text { benefits from its trade liberalization } \\
\text { policies both on the short-run and the } \\
\text { long-run }\end{array}$ \\
\hline $\begin{array}{c}\text { Yavari and } \\
\text { Mohseni (2015) }\end{array}$ & Iran & $\begin{array}{l}\text { Co-integration techniques } \\
\text { and a vector error } \\
\text { correction model }\end{array}$ & $\begin{array}{l}\text { The authors find that trade } \\
\text { liberalization has a significant long run } \\
\text { positive role in dynamic of growth. } \\
\text { The results support the view that the } \\
\text { integration of the Iranian economy } \\
\text { with the world economy is } \\
\text { undoubtedly welfare improving. }\end{array}$ \\
\hline $\begin{array}{l}\text { Tahir and Khan } \\
\text { (2015) }\end{array}$ & 22 Asian countries & $\begin{array}{l}\text { Two-stages least squares } \\
\text { method ( } 2 \text { SLS) }\end{array}$ & $\begin{array}{l}\text { The results show that trade openness } \\
\text { has contributed significantly to the } \\
\text { growth process of the developing } \\
\text { countries located in the Asian region. It } \\
\text { is also found that domestic investment } \\
\text { has influenced economic growth for } \\
\text { the sampled countries. Further, the } \\
\text { results show that human capital has } \\
\text { adversely affected economic growth } \\
\text { despite the fact that different proxy } \\
\text { variables are used. }\end{array}$ \\
\hline $\begin{array}{l}\text { Fetahi-Vehapi, } \\
\text { Sadiku and } \\
\text { Petkovski (2015) }\end{array}$ & $\begin{array}{l}\text { South East European } \\
\text { (SEE) countries }\end{array}$ & Pooled OLS & $\begin{array}{l}\text { The estimation results indicate that the } \\
\text { positive effects of trade openness on } \\
\text { economic growth are conditioned by } \\
\text { the initial income per capita and other } \\
\text { explanatory variables, otherwise there } \\
\text { is no robust evidence between these } \\
\text { two variables. Moreover, the trade } \\
\text { openness is more beneficial to } \\
\text { countries with higher level of initial } \\
\text { income per capita, as well as trade } \\
\text { openness favours countries with higher } \\
\text { level of FDI and with higher gross } \\
\text { fixed capital formation. }\end{array}$ \\
\hline
\end{tabular}




\begin{tabular}{|c|c|c|c|}
\hline $\begin{array}{l}\text { Sikwila et al. } \\
\text { (2014) }\end{array}$ & South Africa & $\begin{array}{l}\text { Auto-Regressive } \\
\text { Distributive Lag (ARDL) }\end{array}$ & $\begin{array}{l}\text { This study confirmed that trade } \\
\text { openness has a significant effect on } \\
\text { economic growth both on the long run } \\
\text { and short run. }\end{array}$ \\
\hline $\begin{array}{l}\text { Umer } \\
(2014)\end{array}$ & Pakistan & $\begin{array}{l}\text { Auto-Regressive } \\
\text { Distributive Lag (ARDL) }\end{array}$ & $\begin{array}{l}\text { The study established that trade } \\
\text { liberalization policies play a key role to } \\
\text { enhance economic growth. }\end{array}$ \\
\hline $\begin{array}{l}\text { Mkubwa et al. } \\
\text { (2014) }\end{array}$ & Tanzania & $\begin{array}{l}\text { Ordinary least square } \\
\text { technique }\end{array}$ & $\begin{array}{l}\text { Finding from the study indicates that } \\
\text { trade openness has a positive and } \\
\text { significant impact on economic growth } \\
\text { in Tanzania. }\end{array}$ \\
\hline $\begin{array}{l}\text { Abbas } \\
(2014)\end{array}$ & $\begin{array}{c}\text { Pakistan, Turkey, } \\
\text { Indonesia and } \\
\text { Philippines, while least } \\
\text { developed countries } \\
\text { include Bangladesh, } \\
\text { Botswana, Mauritius } \\
\text { and Morocco }\end{array}$ & Regression model & $\begin{array}{l}\text { The result shows significant positive } \\
\text { impact of selected macroeconomic } \\
\text { variables on economic growth, except } \\
\text { trade liberalization index. The one unit } \\
\text { increase in trade liberalization } \\
\text { deteriorates economic growth, of } \\
\text { developing countries by US\$ } 280.86 \\
\text { million and least developing by US\$ } \\
3555.09 \text { million. }\end{array}$ \\
\hline $\begin{array}{c}\text { Umoru and } \\
\text { Eborieme (2013) }\end{array}$ & Nigeria & $\begin{array}{l}\text { Johansen Co-integration } \\
\text { and Error Correction } \\
\text { Model }\end{array}$ & $\begin{array}{l}\text { They found a positive relationship } \\
\text { between trade liberalization and } \\
\text { industrial growth in Nigeria. }\end{array}$ \\
\hline $\begin{array}{l}\text { Manni and Afzal } \\
\text { (2012) }\end{array}$ & Bangladesh & $\begin{array}{l}\text { Ordinary least square } \\
\text { technique }\end{array}$ & $\begin{array}{l}\text { The study found that Gross Domestic } \\
\text { Product (GDP) is highly influenced by } \\
\text { trade liberalization thus suggesting that } \\
\text { greater openness has a favourable } \\
\text { effect on economic development in the } \\
\text { investigated country }\end{array}$ \\
\hline $\begin{array}{l}\text { Ezike and Ogege } \\
\text { (2012) }\end{array}$ & Nigeria & $\begin{array}{l}\text { Correlation analysis and } \\
\text { ordinary least square } \\
\text { technique }\end{array}$ & $\begin{array}{l}\text { They found a negative relationship } \\
\text { between trade policy and the non-oil } \\
\text { sector in Nigeria. }\end{array}$ \\
\hline $\begin{array}{l}\text { Ghani } \\
(2011)\end{array}$ & $\begin{array}{l}\text { 41 Organization of the } \\
\text { Islamic Conference } \\
\text { (OIC) member } \\
\text { countries }\end{array}$ & $\begin{array}{l}\text { Vector Error Correction } \\
\text { (VEC) model }\end{array}$ & $\begin{array}{l}\text { The results show that, while in } \\
\text { aggregate there appears to be a positive } \\
\text { but small impact of trade liberalization } \\
\text { on growth, this masks a huge range of } \\
\text { responses. Empirical analysis of this } \\
\text { heterogeneity shows that a one-size- } \\
\text { fits-all policy is not necessarily the } \\
\text { most effective, and suggests a case-by- } \\
\text { case approach is more appropriate. }\end{array}$ \\
\hline $\begin{array}{l}\text { Oladipo } \\
(2011)\end{array}$ & Mexico & $\begin{array}{l}\text { Co-integration and Error } \\
\text { Correction Methods }\end{array}$ & $\begin{array}{l}\text { empirical results suggest that long run } \\
\text { economic growth in Mexico is largely } \\
\text { explained by trade liberalization } \\
\text { (openness) and the level of capital } \\
\text { (investment). }\end{array}$ \\
\hline $\begin{array}{l}\text { Ugurlu } \\
(2010)\end{array}$ & $\begin{array}{c}\text { European Union } \\
\text { organization }\end{array}$ & $\begin{array}{l}\text { Vector Error Correction } \\
\text { (VEC) model }\end{array}$ & $\begin{array}{l}\text { He found a weak relationship between } \\
\text { trade openness and economic growth. }\end{array}$ \\
\hline
\end{tabular}




\begin{tabular}{|c|c|c|c|}
\hline $\begin{array}{c}\text { Rahimi and } \\
\text { Shahabadi } \\
\text { (2011) }\end{array}$ & Iran & $\begin{array}{l}\text { Auto-Regressive } \\
\text { Distributive Lag (ARDL) }\end{array}$ & $\begin{array}{l}\text { Findings from the study suggested that } \\
\text { trade liberalization and economic } \\
\text { growth are co-integrated and that trade } \\
\text { liberalization had a positive and } \\
\text { significant effect on economic growth. }\end{array}$ \\
\hline $\begin{array}{l}\text { Kneller et al. } \\
\text { (2008) }\end{array}$ & $\begin{array}{c}\text { Some Latin American } \\
\text { countries }\end{array}$ & $\begin{array}{l}\text { Auto-Regressive } \\
\text { Distributive Lag (ARDL) }\end{array}$ & $\begin{array}{l}\text { The results show that, while in } \\
\text { aggregate there appears to be a positive } \\
\text { but small impact of trade liberalization } \\
\text { on growth, this masks a huge range of } \\
\text { responses. Empirical analysis of this } \\
\text { heterogeneity shows that a one-size- } \\
\text { fits-all policy is not necessarily the } \\
\text { most effective, and suggests a case-by- } \\
\text { case approach is more appropriate. }\end{array}$ \\
\hline $\begin{array}{l}\text { Ernst } \\
(2005)\end{array}$ & $\begin{array}{c}\text { Argentina, Brazil and } \\
\text { Mexico }\end{array}$ & $\begin{array}{l}\text { Vector error correction } \\
\text { method }\end{array}$ & $\begin{array}{l}\text { Economic opening in Argentina, Brazil } \\
\text { and Mexico did not lead to export } \\
\text { dynamism and had a disappointing } \\
\text { impact on employment, even though } \\
\text { trade liberalization and regional } \\
\text { integration caused a strong increase in } \\
\text { trade and led to a better integration into } \\
\text { the world economy. }\end{array}$ \\
\hline $\begin{array}{l}\text { Wacziarg and } \\
\text { Welch (2003) }\end{array}$ & $\begin{array}{l}118 \text { countries that cut } \\
\text { across Africa, Asia, } \\
\text { Europe, Latin America } \\
\text { and North America }\end{array}$ & $\begin{array}{l}\text { Johansen Co-integration } \\
\text { and Error Correction } \\
\text { Model }\end{array}$ & $\begin{array}{l}\text { They found that liberalization has, on } \\
\text { average, minimal effects on growth, } \\
\text { openness and investment rates within } \\
\text { countries. They illustrate these large } \\
\text { sample findings with detailed case } \\
\text { studies in a subsample of } \\
\text { representative countries. }\end{array}$ \\
\hline $\begin{array}{c}\text { Greenaway, } \\
\text { Morgan and } \\
\text { Wright (2000) }\end{array}$ & & & $\begin{array}{l}\text { The paper finds that liberalization does } \\
\text { appear to impact upon growth, albeit } \\
\text { with a lag. The evidence points to } \\
\text { a } J \text { curve type response and this finding } \\
\text { is robust to changes in specification, } \\
\text { sample size and data period. }\end{array}$ \\
\hline
\end{tabular}

Source: author's compilation

Trade liberalization, ceteris paribus, is expected to increase competition level, efficiency and productivity of the domestic production sectors. It improves resource allocation in line with the marginal cost and benefits, provides access to better technology and inputs and enables countries to take advantage of economies of scale. However, the empirical findings from the prior studies have been largely mixed. A cursory observation of these studies revealed that the mixed results might not be unconnected to variables omitted in the regression analysis, and methodological differences.

Table 1 presents the summary of some prior studies that examined relationship between trade liberalization (or openness) on economic growth. Quite a number of the studies focused on developed and developing economies in Asia, Europe and North America. Dornbusch (1992), Edwards (1993), Sachs and Warner (1995), 
Oladipo (1998), Wacziarg and Welch (2003), Ernst (2005), Oladipo (2011), Rahimi and Shahabadi (2011), Kim (2011), Manni and Afzal (2012), Mkubwa et al. (2014), and Yavari and Mohseni (2015) among others have provided convincing evidence of positive relationship between trade liberalization and economic growth.

On the other hand, empirical studies by Rodrik and Rodriguez (2000), Dollar and Kraay (2002), Wacziarg and Welch (2003), Rodriguez (2007) and Ugurlu (2010) among others have echoed contrary view that trade liberalization is not associated with economic growth. The paper observed that Bhagwati and Srinivasan (2001) analyzed the criticism by Rodrik and Rodriquez (2000) and considered it unpersuasive.

Studies in this area of research on Nigeria is growing. Ekpo and Egwaikhide (1994) examined the relationship between trade and economic growth using annual data between 1959 and 1989. His approach is appealing as he used the cointegration and error correction methods and was able to avoid the pitfalls in prior studies. In the same vein, Ekpo (1995) examines the relationship between openness and the performance of the Nigeria economy between 1970 and 1992. He observed that capital stock and human capital contributed positively to output growth during the period. The empirical study by Oladipo (1998) extended the work by Egwaikhide (1994), Ekpo (1995) and Olomola (1998) as he used different measurement of openness, the ratio of trade (export plus import) to gross domestic product (GDP). Using quarterly data from 1970 to 1996 , he found that the measure of openness correlated positively with the growth of GDP.

Further, Odusola and Akinlo (1995) examined the causal link between trade variables and economic growth in Nigeria between 1960 and 1992. Using Granger causality tests approach, they found bi-directional causal effects between export and economic growth but there was a unidirectional relationship between term of trade and exports. However, similar study by Muhammed and Sampath (1999) echoed a contrary results. We observed that study by Odusola and Akinlo suffered from methodological deficiencies. The study did not examine the basic cointegration properties of the variables. If the variables used in the model were cointegrated, then their model which incorporated the difference variables is mis-specified because the lagged error term was not included, see Granger (1988). Further, the non-inclusion of the error correction term from the cointegration model eliminated any long run information embodied in the original form of the variables. With the exclusion of the error term from the model, it is difficult to detect the channel of Granger causality through the lagged error correction terms.

Umoru and Eborieme (2013) found a positive relationship between trade liberalization and economic growth. Also, recent study by Titus and Abiodun (2017) observed a significant positive impact of trade liberalization on agricultural output but a negative effect on manufacturing output. However, Khobai et al (2018) found evidence of negative and insignificant effect of trade liberalization on economic growth. 
In general, the findings is at best inconclusive as the conclusion cannot be generalized. Thus, there is need for more study to shed more light on the debate.

\section{Methodology}

Following Manwa and Wijeweera (2016) and Manwa et al., (2019) but with slight modifications, the paper adopted the endogenous growth model as the baseline for the research work, where labour; physical capital; human capital; and total factor productivity are considered as the primary determinants of economic growth. Therefore, the endogenous growth hypothesis of long run economic growth within the internal forces may be specified as:

$Y=A L^{\alpha_{1}} K^{\alpha_{2}} Z^{\alpha_{3}} e^{\varepsilon_{t}}$

Where: Y depicts output, A is technology which represent total factor productivity assumed to be a function of trade liberalization, $\mathrm{L}$ depicts labour, $\mathrm{K}$ represents physical capital while $\mathrm{Z}$ represents human capital. Extending equation 1 to incorporate the trade liberalization variables or indicators, we have

$Y=L^{\alpha_{1}} K^{\alpha_{2}} Z^{\alpha_{3}} A\left(T L^{\alpha_{4}}\right) e^{\varepsilon_{t}}$

Where: $A=A\left(T L^{\alpha_{4}}\right)$, thus, the growth of output is a function of labour force, capital, and human capital. The measure of trade liberalization TL, which is a policy variable, is assumed contribute to output. In equation 2, TL also represents the vector of trade liberalization indicators. Using logarithm, equations 1 and 2 can be rewritten as:

$\operatorname{Ln} Y_{t}=\alpha_{0}+\alpha_{1} \operatorname{Ln} L_{t}+\alpha_{2} \operatorname{LnK}_{t}+\alpha_{3} \operatorname{LnZ} Z_{t}+\alpha_{4} T L_{t}+\varepsilon_{t}$

As mentioned earlier, A represents technology which is an essential ingredient for economic growth. In equation 3, the impact of technology is often transmitted through human and physical capitals. Since one of the objectives of the paper is to test whether the choice of trade liberalization indicator matters for economic growth, the paper employs three different indicators of trade liberalization which are: trade ratio or openness (OPN), tariff rates (RT) and the real effective exchange rates (ER). For the purpose of this study, OPN is measured as the sum of export, import and services to GDP while RT represent incidence based category of trade liberalization and we expect that it will have negative effects on economic growth. Finally, the third indicator, ER represents the price based category of trade liberalization. A negative coefficient on ER will imply currency depreciation while a positive coefficient will represent currency appreciation. From the theoretical point, ER coefficient would be negative as currency depreciation is expected to encourage domestic production as the cost of imports will increase. Thus, there will be increase in demand for domestic products globally. 
The paper uses quarterly time series data from 1981q1 to 2018q4 which translate to 152 observation. This is relatively large when compared with previous studies. The data for the study is obtained from the Central Bank of Nigeria (CBN), Statistical Bulletin and the World Bank and Penn World Tables (PWT). In line with the specified endogenous growth theory, the labour force is expected to have a positive influence on growth. The variable $K$ denoting physical capital measured as log of gross fixed capital information while $Z$ representing human capital is measured as log of human capital index obtained from PWT. Trade liberalization indicators, TL regarded as outcome-based liberalization is measured as the sum of total export and import of goods and services to the country's GDP, World Bank (2014) and is expected to have positive impact on economic growth. For RT which is described as incidence-based category of liberalization, it is measured as log of average nominal tariff rates on all products and it is expected to have negative effects on economic growth, see Manwa et al. (2019). Finally, ER which is the third indicator of liberalization is expected to have a negative coefficient which connotes currency depreciation while a positive coefficient will imply currency appreciation.

\section{Empirical Results and Discussions}

Table 2 presents the summary statistics of the series; where the average economic growth measure as real GDP is $\$ 33.7$ billion for the period under consideration. Compared to the average trade openness which is only 32.2 percent of the sum of export and import as ratio of GDP, the average trade restriction policy tariffs rate, for instance, is as high as 22.1 percent which is typical of developing economies such as Nigeria. For the standard deviation statistics which measures the degree of the dispersion of the series from their mean level, the value seems to be exact for both trade openness policy at 12.59 and trade restrictiveness policy at 12.95. This suggests that variations in trade policies have been due to equal concerns from both the perspectives of trade openness and trade restrictions.

With respect to the distribution statistics, all the series are positively skewed but the result is mixed for kurtosis statistics. The kurtosis statistic, for instance, is platykurtic for RT, ER and K, while it is leptokurtic for Y, L, Z and OPN. Due, in part, to the fact that the skewness statistics for $\mathrm{L}, \mathrm{Z}$ and OPN does not seem to differ from zero tends to be supporting the largeness of the p-value associated with the Jarque-Bera (JB) test for these series, which suggests that they are normally distributed. However, the null hypothesis of normal distribution seems to be rejected for Y, K, RT and ER. 
Table 2: Summary Statistics

\begin{tabular}{|c|c|c|c|c|c|c|c|}
\hline Statistic & $\mathbf{Y}$ & $\mathbf{L}$ & $\mathbf{K}$ & $\mathbf{Z}$ & OPN & RT & ER \\
\hline Mean & $3,725.22$ & 40.88 & 56.54 & 1.49 & 32.26 & 22.14 & 150.45 \\
\hline Maximum & $69,810.02$ & 62.91 & 105.06 & 1.94 & 53.28 & 87.19 & 541.46 \\
\hline Minimum & $13,779.26$ & 27.03 & 37.72 & 1.20 & 9.14 & 9.94 & 50.17 \\
\hline Std. Dev. & $19,578.10$ & 11.16 & 13.17 & 0.26 & 12.56 & 12.95 & 121.23 \\
\hline Skewness & 0.73 & 0.45 & 1.49 & 0.33 & 0.35 & 3.27 & 1.83 \\
\hline Kurtosis & 2.00 & 1.94 & 6.33 & 1.65 & 2.19 & 17.87 & 5.49 \\
\hline Jarque-Bera & 5.01 & 3.10 & 31.74 & 3.59 & 1.83 & 418.17 & 31.06 \\
(JB test) & $(0.08)$ & $(0.21)$ & $(0.00)$ & $(0.17)$ & $(0.40)$ & $(0.00)$ & $(0.00)$ \\
\hline
\end{tabular}

Note: the value in parenthesis is probability value associated with the JB test

As a precondition for dealing with time series, this study further subjected each of the series to unit root tests. For robustness, it considered both the Augmented Dickey-Fuller (ADF) test and Philip Perron (PP) tests. Presented in Table 3 is the unit root test result which is performed on the natural logarithm of the series. A cursory observation of Table 3 shows that none of the variables are stationary at level. The unit root test at first difference revealed that all the series are stationary, that is, all the series are $\mathrm{I}(1)$.

Table 3: Unit Root Test Results

\begin{tabular}{|c|c|c|c|c|c|c|}
\hline & \multicolumn{2}{|c|}{ Augmented Dickey Fuller (ADF) test } & \multicolumn{3}{|c|}{ Philip Perron (PP) test } \\
\cline { 2 - 7 } & Level & $\begin{array}{c}\text { First } \\
\text { Difference }\end{array}$ & $\mathrm{I}(\mathrm{d})$ & Level & $\begin{array}{c}\text { First } \\
\text { Difference }\end{array}$ & $\mathrm{I}(\mathrm{d})$ \\
\hline$Y_{t}$ & -1.215 & $-4.780^{*}$ & $\mathrm{I}(1)$ & -1.402 & $-5.322^{*}$ & $\mathrm{I}(1)$ \\
\hline$L_{t}$ & -2.210 & $-5.401 *$ & $\mathrm{I}(1)$ & -2.255 & $-6.029^{*}$ & $\mathrm{I}(1)$ \\
\hline$K_{t}$ & -1.231 & $-6.102^{*}$ & $\mathrm{I}(1)$ & -1.370 & $-6.309^{*}$ & $\mathrm{I}(1)$ \\
\hline$Z_{t}$ & -1.102 & $-4.981 *$ & $\mathrm{I}(1)$ & -1.321 & $-5.841^{*}$ & $\mathrm{I}(1)$ \\
\hline$O P N_{t}$ & -1.009 & $-8.471^{*}$ & $\mathrm{I}(1)$ & -1.304 & $-9.077^{*}$ & $\mathrm{I}(1)$ \\
\hline$R T_{t}$ & -1.201 & $-7.951^{*}$ & $\mathrm{I}(1)$ & -1.402 & $-8.482^{*}$ & $\mathrm{I}(1)$ \\
\hline$E R_{t}$ & -0.948 & $-5.960 *$ & $\mathrm{I}(1)$ & -1.081 & $-6.902^{*}$ & $\mathrm{I}(1)$ \\
\hline
\end{tabular}

Note: The exogenous lags are selected based on Schwarz info criteria. The paper uses Eviews 10.0 for stationary tests, $*$ denotes variable is significant at 5 percent. The critical values of the ADF and PP statistics with a constant but no trend are $-3.47,-2.88$, and -2.57 at the 1,5 and 10 percent levels, while tests statistics with a constant and trend are $-4.01,-3.43$, and -3.14 at the 1,5 and 10 percent levels.

Next, to capture the potential long run dynamics, Johansen cointegration technique is used, for details see Johansen (1981) and Johansen, S., Juselius, K. (1992). Since the variables in the first differences can accommodate more than one lag, 
determining the optimal lag combination for the cointegration test becomes necessary. The optimal lag length is selected using Schwartz Information Criterion $(\mathrm{SIC})^{3}$. The model shows that a VAR with four lags (this implies a lag length of three in the VEC model) is the best system to test for a long run relationship among the variables ${ }^{4}$. Table 4 presents the Johansen test results.

Table 4: Cointegration Test

Co-integration results (with a linear trend) where $r$, is the number of co-integrating vectors ${ }^{5}$

\section{Panel (1): Estimates of $\lambda$ max and trace tests}

Null Alternative $r \quad \lambda \max \quad$ Critical value (95\%) Trace Critical vale $(95 \%)$

\begin{tabular}{llllll}
\hline 0 & 1 & 36.40 & 32.78 & 73.22 & 66.70 \\
$\leq 1$ & 2 & 20.12 & 26.09 & 46.77 & 48.46 \\
$\leq 2$ & 3 & 19.34 & 22.91 & 26.67 & 29.74 \\
$\leq 3$ & 4 & 10.09 & 14.65 & 10.48 & 16.09 \\
$\leq 4$ & 5 & 00.54 & 03.88 & 00.67 & 03.88
\end{tabular}

Panel (2): Estimates of co-integrating vector

\begin{tabular}{lllllll}
$\mathrm{Y}$ & $\mathrm{L}$ & $\mathrm{K}$ & $\mathrm{Z}$ & $\mathrm{OPN}$ & $\mathrm{RT}$ & $\mathrm{ER}$ \\
\hline
\end{tabular}

$1.000 \quad-0.91(-4.9)-0.52(-5.1) \quad-0.44(-2.4) \quad-0.51(-3.1) \quad 0.31(2.9)-0.51(-4.4)$

From Table 4, panel 1 shows both the maximum eigenvalue and trace statistics for the cointegration tests. Using the using $\lambda$-max and the trace statistics, the null hypothesis of no cointegration is rejected as they are greater than their critical values at 5 percent level of significance. The results indicate that there exist a unique cointegrating vector among the variables. Panel 2 of Table 4 reports the cointegrating equation normalized which reveal that all variables are positive except RT (the sign are reversed because of the normalized process). Also, the coefficients are all significant as indicated by the $\mathrm{t}-$ ratio in parentheses.

Following Banerjee et al. (1998) the paper uses the error correction model to examine the dynamics relationship among the variables.

\footnotetext{
3 The lag combination with the least value of the chosen criterion among the competing lag orders is considered the optimal lag.

4 The diagnostic test results are available upon request.

5 The results are without constant, but when a constant was introduced the results are not significantly different.
} 
$\Delta \ln Y_{t}=\sum_{j=1}^{p} \alpha_{1} \Delta Y_{t-j}+\sum_{i=0}^{q_{2}} \alpha_{2} \Delta \ln L_{t-i}+\sum_{i=0}^{q_{3}} \alpha_{3} \Delta \ln K_{t-i}+\sum_{i=0}^{q_{4}} \alpha_{4 i} \Delta \ln Z_{t-i}+\sum_{i=0}^{q_{5}} \alpha_{5 i} \Delta T L_{t-i}$
$+\alpha_{6} E C_{t-1}+\mu_{t}$

Where: $E C_{t-1}$ depicts the lagged value of the error correction term in equation 4 and $\alpha_{6}$ is the error correction coefficient.

Table 5: Results of Error Correction Model (dependent variable $\Delta \ln Y_{t}$ )

\begin{tabular}{|c|c|c|}
\hline Regressors & Parameter Estimates & t - probability \\
\hline Intercept & 1.745 & 0.0288 \\
\hline$\Delta \ln Y(-1)$ & 0.057 & 0.0078 \\
\hline$\Delta \ln Y(-2)$ & 0.139 & 0.0672 \\
\hline$\Delta \ln Y(-3)$ & 0.238 & 0.0220 \\
\hline$\Delta \ln L(-2)$ & 0.241 & 0.0016 \\
\hline$\Delta \ln L(-3)$ & 0.251 & 0.1087 \\
\hline$\Delta \ln L(-4)$ & 0.194 & 0.0231 \\
\hline$\Delta \ln K(-2)$ & 0.310 & 0.0041 \\
\hline$\Delta \ln K(-3)$ & 0.428 & 0.0003 \\
\hline$\Delta \ln Z(-2)$ & 0.240 & 0.0033 \\
\hline$\Delta \ln Z(-3)$ & 0.160 & 0.0045 \\
\hline$\Delta \ln O P N(-1)$ & 0.272 & 0.0000 \\
\hline$\Delta \ln O P N(-3)$ & 0.408 & 0.0006 \\
\hline$\Delta \ln R T(-2)$ & -0.129 & -0.4434 \\
\hline$\Delta \ln R T(-4)$ & -0.019 & -0.7238 \\
\hline$\Delta \ln E R(-2)$ & -0.203 & -0.0012 \\
\hline$\Delta \ln E R(-3)$ & -0.026 & -0.0119 \\
\hline EC & -0.159 & -0.0017 \\
\hline Adj. R- squared 0.987 & & \\
D.W. $=2.18$ & & \\
Serial Correlation $1.308(0.2301)$ & \\
RESET $0.01(0.7850)$ & & \\
Normality =0.384 $(0.6489)$ & & \\
HET =0.04 (0.6749) & & \\
\hline
\end{tabular}

Table 5 presents the results of the error correction model. The error correction coefficient of -0.159 is significant and correctly signed at the 5 percent level which implies that the system is able to correct its previous period's disequilibrium by 
approximately 20 percent a quarter. In what appears to be consistent with our apriori expectation, the study finds trade liberalization with the potential of causing increasing economic growth, particularly when measured as a ratio of the sum of import and export to GDP. However, the coefficient on ER is negative and statistically significant and appears to differ from previous studies that had shown that the undervaluation of the exchange rate can have a positive impact on economic growth of developing countries, see Rodrik (2008), Eichengreen (2007), and Hausmann et al., (2005).

An equally interesting finding is the negative but insignificant impact of RT on economic growth, thus suggesting that a tariff reduction is not likely to exhibit any significant impact on economic growth in Nigeria. Similar evidence was found by Manwa et al. (2019) for Southern African Custom Union (SACU) countries.

However, the fact that our finding of significant impact of trade liberalization on the economy is only viable and evident on the short run is not entirely unique to the present study. Our finding seems to have been supported in the classical growth models prediction under the assumption of constant returns to scale, that the removal of trade restrictions should not have a permanent effect on long run economic growth, see Krugman and Obstfeld (2008) and Salvatore (2011).

\section{Conclusion and policy recommendations}

Using Nigeria's economy as a case study, this paper has attempted to offer a robust insight on the extent to which trade liberalization matters for economic growth. Exploring Vector Error Correction (VEC) framework, the researchers considered three alternative measures of trade liberalization to determine whether the response of economic growth to trade liberalization is sensitive to which indicators of trade liberalization is under consideration. Essentially, the study found significant effects of trade liberalization in terms of trade openness on economic growth thus confirming the classical growth models prediction that the removal of trade restrictions may have effect on long run economic growth. The paper recommends that government should implement policies that will promote trade openness in Nigeria. This may be achieved by establishing bilateral and multi-lateral agreements that are favourable and that will support appropriate technology transfer to domestic producers. 


\section{References}

[1] Abbas S. (2014) Trade liberalization and its economic impact on developing and least developed countries. Journal of International Trade Law and Policy, September 2014

[2] Anderson, J.E. and Neary, J.P. (1996). A new approach to evaluating trade policy. Review of Economic of Study, 63(1), pp. 107-125.

[3] Anderson, J.E. and Neary, J.P. (2003). The mercantilist index of trade policy. International Economic Review, 44(2), pp. 627-649.

[4] Bhagwati, Jagdish. (1978) Anatomy and Consequences of Exchange Control Regimes. Cambridge, MA: Ballinger for the National Bureau of Economic Research.

[5] Bhagwati, J. and Srinivasan, T. (2002). Trade and poverty in the poor countries. American Economic Review. 92 (2), pp. 180-183.

[6] Bhattacharyya, S. (2012). Trade liberalization and institutional development. Journal of Policy Model, 34(2), pp. 253-269.

[7] Doganlar, M. (2002). Estimating the impact of exchange rate volatility on exports: Evidence from Asian countries. Applied Economic Letter, 9(13), pp. 859-863. http://dx.doi.org/10.1080/13504850210150906

[8] Dollar, D. and Kraay, A. (2004). Trade, growth, and poverty. Economic Journal, 114(493), pp. 22-49. http://dx.doi.org/10.1111/j.00130133.2004.00186.x.

[9] Dornbusch R, (1992) The Case for Trade Liberalization in Developing Countries. Journal of Economic Perspectives, 6 (1), pp 69 - 85

[10] Dowrick, S. and Golley, J. (2004). Trade openness and growth: Who benefits? Oxford Review of Economic Policy, 20(1), pp. 38-56.

[11] Edwards, S. (1993). Openness, Trade Liberalization, and Growth in Developing Countries. Journal of Economic Literature, 31(3), 1358-1393.

[12] Eichengreen, B. (2007). The real exchange rate and economic growth. Social Economic Study, 56(4), pp. 7-20. http://dx.doi.org/10.2307/27866525.

[13] Ekpo, A.H. and F.O. Egwaikhide. (1994), "Export and Economic Growth: A Reconsideration of the Evidence"; Journal of Economic Management 1(1):100-118.

[14] Ekpo, A.H. (1995) "Openness and economic performance in Nigeria: A time series approach", Selected Paper for the 1995 Annual Conference The Nigerian Economic Society.

[15] Ezike, J.E and Ogege, S. (2012). Nigerian foreign trade policy: Its impact on non-oil exports. Journal of Economics and International Finance, 4(8), pp. 192200.

[16] Fetahi-Vehapi, M., Sadiku, L. \& Petkovski, M., 2015, 'Empirical analysis of the effects of trade openness on economic growth: An evidence for South East European Countries', Procedia Economics and Finance 19, 17-26. https://doi.org/10.1016/ S2212-5671(15)00004-0 
[17] Ghani, G. M. (2011). The Impact of Trade Liberalisation on the Economic Performance of OIC Member Countries. Journal of Economic Cooperation and Development, 32(1), 1-18.

[18] Gnangnon, S.K. (2018). Multilateral trade liberalization and economic growth. Journal of Economic Integration, 33(2), pp. 126-1301.

[19] Granger, C.W.J.(1988), "Some Recent Developments in a Concept of Causality"; Journal of Econometrics 39: 199-211.

[20] Greenaway, David, C. Wyn Morgan, and Peter Wright. (2000) Trade Reform, Adjustment and Growth: What Does the Evidence Tell Us? Economic Journal 108: $1547-61$.

[21] Greenaway, D., Morgan, W. and P. Wright (2002). Trade liberalization and growth in developing countries. Journal of Development Economics, 67(1), pp. $229-244$.

[22] Harrison, A. (1996). Openness and growth: A time-series, cross-country analysis for developing countries. Journal of Development Economics, 48, pp. 419-447.

[23] Hausmann, R., Pritchett, L. and Rodrik, D. (2005). Growth accelerations. Journal Economic Growth, 10(4), pp. 303-329.

[24] Hozouri, N. (2016). The effect of trade liberalization on economic growth: Selected MENA Countries. International Journal of Economics and Finance, 9(1), pp. 88-95. http://dx.doi.org/10.1016/j.jpolmod.2011.08.005. https://papers.ssrn.com/sol3/papers.cfm?abstract_id=1976299.

[25] Johansen, S. (1988), "Statistical Analysis of Cointegrating Vectors"; Journal of Economic Dynamics and Control 12:231-254.

[26] Johansen, S., Juselius, K. (1992), Testing structural hypothesis in a multivariate cointegration analysis of the PPP and the UIP for UK. Journal of Econometrics, 53, 211-244.

[27] Keho, Y. and Wang, M. (2017). The impact of trade openness on economic growth: The case of Cote d'Ivoire", Cogent Economics and Finance, 5(1), pp. $1-14$.

[28] Khobai, H. Abel, S. and Le Roux, P. (2016). Co-integration between electricity supply and economic growth in South Africa. International Journal of Energy Economics and Policy, 6(3), pp. 637-645.

[29] Khobai, H. and Chitauro, C. (2018). The impact of trade liberalization on economic growth in Switzerland. MPRA Paper No. 89884, https://mpra.ub.uni-muenchen.de/89884/

[30] Kim, D.-H., (2011) Trade growth and income. J. Int. Trade Econ. Dev. 20 (5), $677-709$.

[31] Kneller, R., Morgan, C. W., \& Kanchanahatakij, S. (2008). Trade Liberalisation and Economic Growth. World Economy, 31(6), 701-719.

[32] Krugman, P.R. and Obstfeld, M. (2008). International Economics: Theory and Policy. MA: Pearson, Boston 
[33] Manni, H.M and Afzal, M.N.I (2012). Effect of trade liberalization on economic growth of developing Countries: A Case of Bangladesh Economy. Journal of Business, Economics and Finance, 1(2).

[34] Manwa, F. and Wijeweera, A. (2016). Trade liberalization and economic growth link: The case of Southern African custom union countries. Econ. Anal. Policy, 51, pp. 12-21.

[35] Manwa, F., Wijeweera, A. and Kortt, M. (2019). Trade and growth in SACU countries: A panel data analysis. Economic Analysis and Policy, 63, pp. 107118

[36] Mkubwa, H.M, Mtengwa, B.A. and Babiker, S. (2014). The impact of trade liberalization on economic growth in Tanzania. International Journal of Academic Research in Business and Social Sciences, 4(5), pp. 514-532.

[37] Moyo, C. \& Khobai, H., 2018, Trade openness and economic growth in SADC countries, MPRA Paper No. 84254, viewed n.d., from https://mpra.ub.unimuenchen.de/ 84254/

[38] Muhammed, S. A. and Sampath, R. K. (1999) Exports and economic growth", Indian Economic Journal, 47(3): 79-88.

[39] Nteegah, A., Nelson, M. and Owede, V.M. (2017). Trade liberalization and economic growth in Nigeria. International Journal of Social Science and Economics Invention, 3(1).

[40] Odusola, A. F and Akinlo (1995) Trade, growth and causality in Nigeria", a Selected Paper for the 1995 Annual Conference of Nigerian Economic Society.

[41] Oladipo, O. S (1998) Trade liberalization and economic growth in Nigeria", Ife Social Sciences Review, 15(1): 80-92. 30

[42] Oladipo, O.S (2011). Does Trade Liberalization Cause Long Run Economic Growth in Mexico? An Empirical Investigation. International Journal of Economics and Finance, Vol 3, No.3.

[43] Olomola, P. A (1998) Openness and long run economic growth in Nigeria 1960-1998", Journal of Economic Management, 5(1): 39-61.

[44] Rahimi, M. and Shahabadi, A. (2011). Trade liberalization and economic growth in Iranian economy.

[45] Rodríguez, F. and Rodrik, D. (2000). Trade policy and economic growth: A skeptic's guide to the cross-national evidence. In: NBER/Macroeconomics Annual, 15 (1), MIT Press, pp. 261-325.

[46] Rodrik, D. (2008). The real exchange rate and economic growth. Brook. Pap. Econ. Act. 39(2), pp. 365-439.

[47] Rodrik, D. (2016). An African growth miracle? Journal of African Economies, 27(1), pp. 10-27.

[48] Salvatore, D. (2011). International Economics: Trade and Finance, tenth ed. John Wiley and Sons, Inc., Hoboken, NJ.

[49] Sikwila, N., Ruvimbo, N. and Mosikari, T. (2014). Trade openness and GDP Growth nexus in South Africa. Global Journal of Management and Business Research, 14(7), pp. 1-7. 
[50] Tahir, M. and Ali, H.N. (2014). Trade openness and economic growth: A review of the literature. Asian Social Science, 10(9), pp. 137-143.

[51] Titus, O. and Abiodun, A. (2017). Trade liberalization and economic performance in Nigeria: Evidence from Agricultural and Manufacturing sectors. African Journal of Economic Review, 5(3), pp. 1-12.

[52] Ugurlu, E. (2010), "Growth and openness relationship in the EU-15: panel data analysis", Ekonomika,Vol.89No.2,pp.44-54.

[53] Umer, F. (2014). Impact of trade openness on economic growth of Pakistan: An ARDL Approach. Journal of Business and Economic Policy, 1(1), pp. 3959.

[54] Umoru, D. and Eborieme, M (2013) 'Trade Liberalization and Industrial Growth in Nigeria', Journal of Poverty, Investment and Development $1 \mathrm{pp}$. 148-156.

[55] Wacziarg, R. (2001). Measuring the dynamic gains from trade. World Bank Economic Review, 15(3), pp. 393-429.

[56] Wacziarg, R. and Welch, H.K. (2003) Trade Liberalization and Economic Growth: New Evidence, NBER Working Paper No. 10152, Vol. 22 No. 2, pp. 187-231.

[57] Yanikkaya, H. (2003). Trade openness and economic growth: A cross-country empirical investigation. Journal of Development Economic, 72(1), pp. 57-89. http://dx.doi.org/10.1016/s0304-3878(03)00068-3. 